\title{
Healthy urban space ratios through Environmental and Human Aspects
}

\author{
Arch. Esraa Ebrahiem Ebrahiem \\ Demonstrator, Department of Architecture \\ Obour engineering institutes \\ rokasalim92@gmail.com \\ Prof. M Alaa Mandour \\ Prof. of Arch.\& Building \\ Technology at Arch. Department \\ Helwan University \\ Cairo, Egypt \\ alaa_mandour2004@yahoo.com \\ Associate Prof. Tarek Mostafa Sobhy \\ Assistant Prof. at Arch. Department \\ Helwan University \\ Cairo, Egypt \\ line 4: e-mail address
}

\begin{abstract}
Since the early days of the COVID-19 epidemic, the scientific community has continuously been trying to shed light on various issues such as the mechanisms driving the spread of the virus, its environmental and socio-economic impacts, and required recovery and adaptation plans and policies. Given the high concentration of population and economic activities in cities, they are frequently spotted by COVID-19 infections.

Changes in infectious disease transmission patterns are a likely major consequence of climate pollution. The population now lives in urban areas, we found a consistent negative association between urban green space exposure and mortality, heart rate, and violence, and positive association with wellbeing, attention, and physical activity.

The built environment, natural and social environments have a significant effect on health and wellbeing. The design and construction of new communities provide an opportunity to explore neighborhood's' design and planning for human health. Neighborhood design can contribute to a sense of place and the health of residents by changing the ratios of the car lanes, pedestrian paths, cycle lanes, green spaces, and public spaces for people.
\end{abstract}

Keywords; healthy spaces; new urbanism; urban ratios; air temperature; air quality; PMV.

\section{INTRODUCTION}

urban design factors can affect public health in several ways, including physical activity, traffic accident risk, and sound level, pollution exposure, access to health resources, mental health, and affordability, which affect a household's ability to affordability.

The impact of the physical environment on health and well-being has become a common concern of the "new urbanism" called for the reintegration of public health and urban design. The application of human needs in urban space includes air and water clean, safety, transportation, social interaction, and open space for leisure. Can lead to environmental space through:

- $\quad$ Reduction of urban fabric imbalances.

- Car use, air, and noise pollution. 
- $\quad$ quality of public spaces, social cohesion.

- Healthy lifestyles and increase employment opportunities

\section{Problem DEFINITION}

1- The major causes of death and injury in the urban environment today include alcohol, tobacco, drugs, environmental toxins, motor vehicles, and weapons such as guns and knives. These are all areas where the formal health sector has relatively little impact on human health.

2- Public health research indicates that bad social relationships affect human health.

3- planning policies actually incompatible with human health, in particular rigid standards of zoning and design.

4- urban spaces ratios effects on viruses spread which affect on human health

\section{METHODOLOGY}

in this study, we will apply some changes in Egyptian urban spaces design ratios in three locations including in streets, transportation, public space, green area, buildings to examine the change in space pollution and human thermal comfort. to get healthy urban spaces for people.

\section{IMPLEMENTATION IN EGYPT}

Egyptian zoning practices, requiring greater travel distances between where we live, work, and play, may be counter to the original health intent because of car culture, city planning and its allied professions have become aware of the health impacts that our land use and transportation decisions have on the ability to walk and bike, the most common forms of physical activity.

green space in urban areas, is good for health and wellbeing. It has been associated with reducing feelings of stress, increased levels of physical activity, more opportunities for social interaction and assisting in child development, releasing oxygen provide clean air, water and soil, and balances in Egyptian natural urban environment.

\section{A- The Simulation PROGRAMME}

The simulation study was undertaken to assess the effects of redesign urban space ratios on human health. the adaptive use of a climatic modeling software innovation named ENVI-met, the program used to model climatic models of general structural changes or structural modifications that include elements of the natural and built environment such as vegetation, buildings, roads, soil and also climatic behavior simulation of people.

\section{B- THE SIMULATION DATA}

- Simulation date: $1 / 7 / 2020$

- Simulation time: 16:00

- climate data from energy plus program.

Table 1 Climate data

\begin{tabular}{|l|c|}
\hline $\begin{array}{l}\text { Wind Direction } \\
\text { (0:N..90:E..180:S..270:W..) }\end{array}$ & 240 \\
\hline Roughness Length z0 at Reference Point & 0.1 \\
\hline Initial Temperature Atmosphere [K] & 318.5 \\
\hline Specific Humidity in 2500 m & 10.8 \\
\hline Relative Humidity in 2m [\%] & 13 \\
\hline
\end{tabular}


- Table 2 PMV data

\begin{tabular}{|c|c|}
\hline PMV & 1.1 \\
\hline Walking Speed $(\mathrm{m} / \mathrm{s})$ & 133 \\
\hline Energy-Exchange & 0 \\
\hline Mech. Factor & 0.5 \\
\hline
\end{tabular}

\section{- Table 3 building data}

\begin{tabular}{|l|c|}
\hline \multicolumn{1}{|c|}{ BUILDING } & \\
\hline Inside Temperature $[\mathrm{K}]=$ & 305 \\
\hline Heat Transmission Walls $\left[\mathrm{W} / \mathrm{m}^{2} \mathrm{~K}\right]=$ & 0.5 \\
\hline Heat Transmission Roofs $\left[\mathrm{W} / \mathrm{m}^{2} \mathrm{~K}\right]=$ & 0.4 \\
\hline Albedo Walls $=$ & 0.3 \\
\hline
\end{tabular}

\section{- Table 4 soil data}

\begin{tabular}{|l|l|}
\hline Car lane, parking & Asphalt Road \\
\hline Bike lane & Brick Road (yellow stone) \\
\hline Pedestrians and building & Loamy Soil \\
\hline
\end{tabular}

\section{Table 5 soil temperature data}

Loamy Soil

\begin{tabular}{|l|l|}
\hline \multicolumn{2}{|c|}{ Soildata } \\
\hline Initial Temperature Upper Layer $(0-20 \mathrm{~cm}) \mathrm{K}$ & 318.5 \\
\hline Initial Temperature Middle Layer $(20-50 \mathrm{~cm}) \mathrm{k}$ & 318.5 \\
\hline Initial Temperature Deep Layer (below $50 \mathrm{~cm}) \mathrm{K}$ & 315.5 \\
\hline
\end{tabular}

Table 6 plants data. Initial Temperature Middle Layer $(20-50 \mathrm{~cm}) \mathrm{k}$ 315.5

\begin{tabular}{|l|}
\hline \multicolumn{1}{|c|}{ plants } \\
\hline - Tree $4 \mathrm{~m}$ dense, Ficus Netida \\
\hline - Tree $10 \mathrm{~m}$ very dense, leafless base \\
\hline - Grass $8 \mathrm{~cm}$ aver height \\
\hline
\end{tabular}

\section{C- Case Studies and simulation}

\section{C.1- OBOUR CITY}

Obour city is second generation Satellite city located around and close to Cairo with a short and middle term objective of minimizing population density and benefiting from the available basic structures such as services, and labor in attracting population, activities, creating new job opportunities, and economic elements that are associated with the mother city.

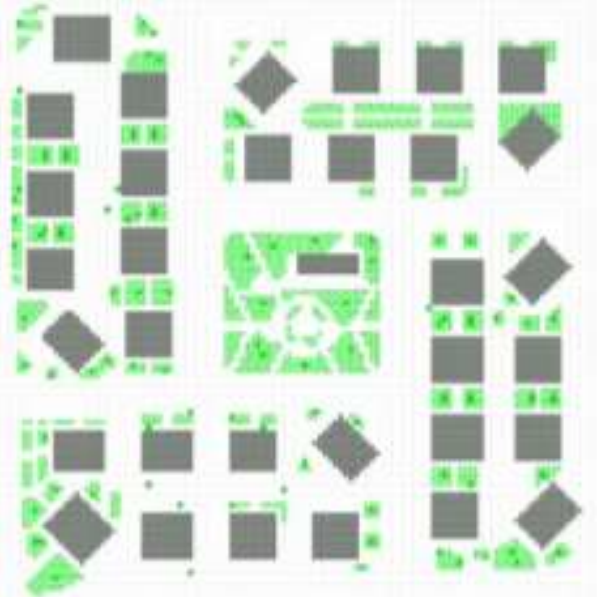

Figure 1 show the urban planning of the location.

Source: Envi mat programme. 
- TABLE 7 EVALUATION OF SPACE. source: By the researcher

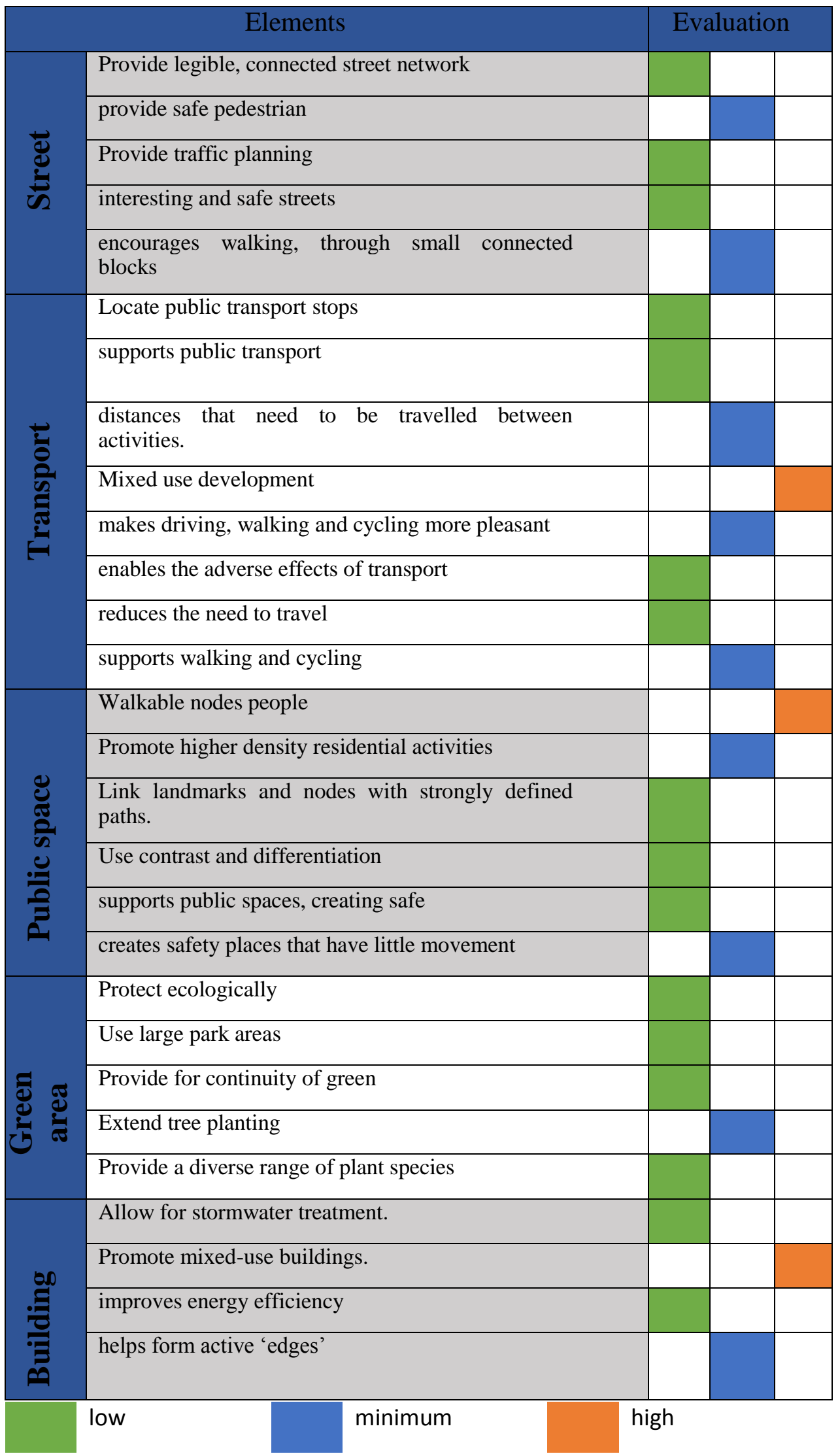


Table 8 Ratios of the urban elements in the simulation. source: By the researcher

\begin{tabular}{|c|l|l|}
\hline & before & after \\
\hline public space & 2.6 & 7 \\
\hline green area & 9.8 & 12.8 \\
\hline car road & 23.7 & 13 \\
\hline pedestrians & 46.5 & 42 \\
\hline cycle lane & 0 & 7.8 \\
\hline building & 17.4 & 17.4 \\
\hline
\end{tabular}

- The car road ratio includes $3 \%$ for parking area

- Buildings in new design have green roof for storm water management.

SIMULATION RESULTS IN OBOUR CITY

1-Figure 2 Air temperature reduction is $2: 3$ oC after redesign. source: By the researcher

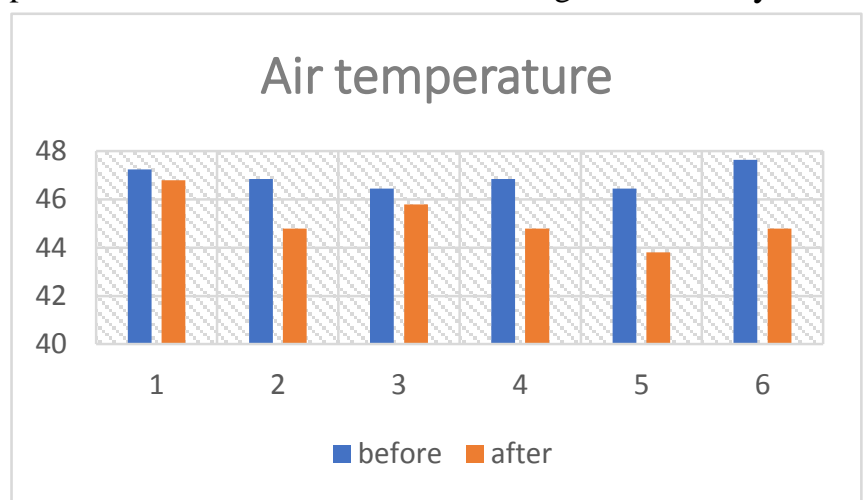

2- Figure 3 Relative humidity ratio reduction is $1 \%-1.4 \%$. source: By the researcher

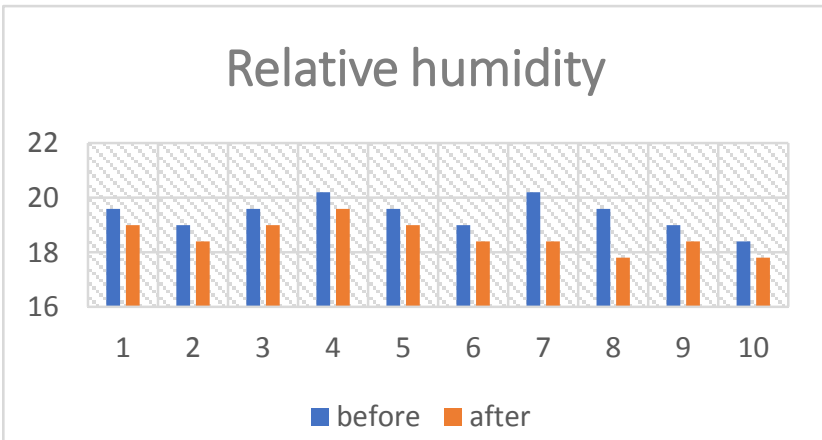

3-Figure 4 Wind speed reduction is $0.5 \mathrm{~m} / \mathrm{s}: 1 \mathrm{~m} / \mathrm{s}$. source: By the researcher

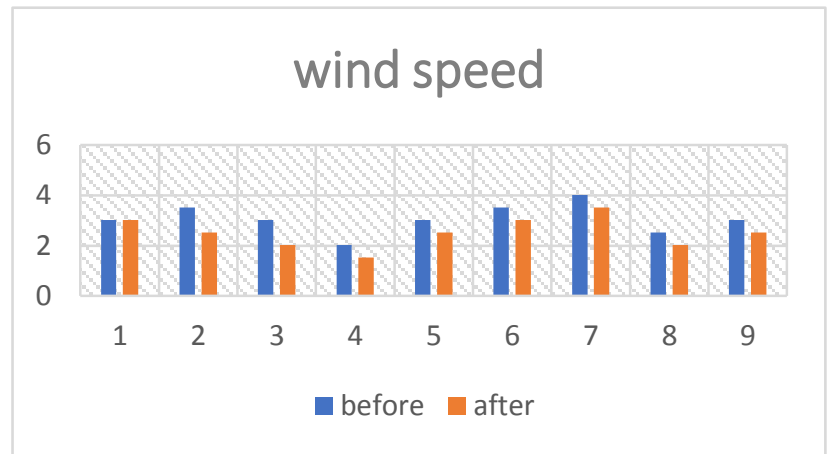


4- Figure $5 \mathrm{Co}_{2}$ reduction average is $0.2 \mathrm{mg} / \mathrm{m}^{3}$ in the space. source: By the researcher

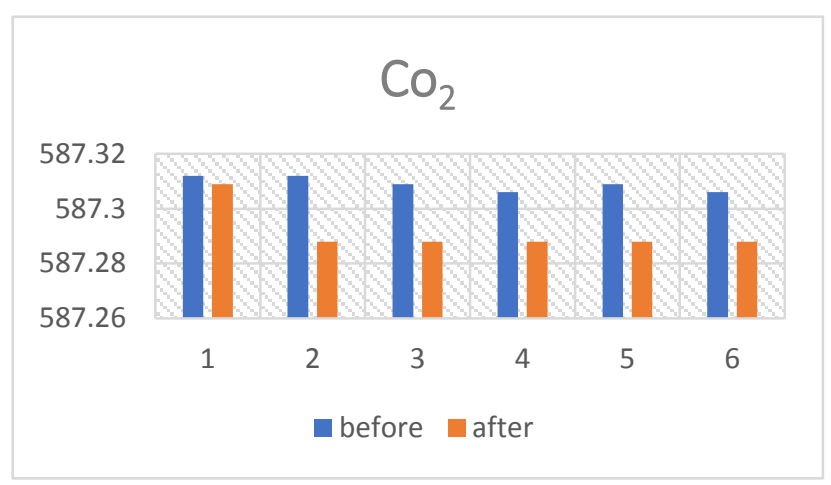

5- Figure 6 PMV reduction average is 2 in urban space. source: By the researcher

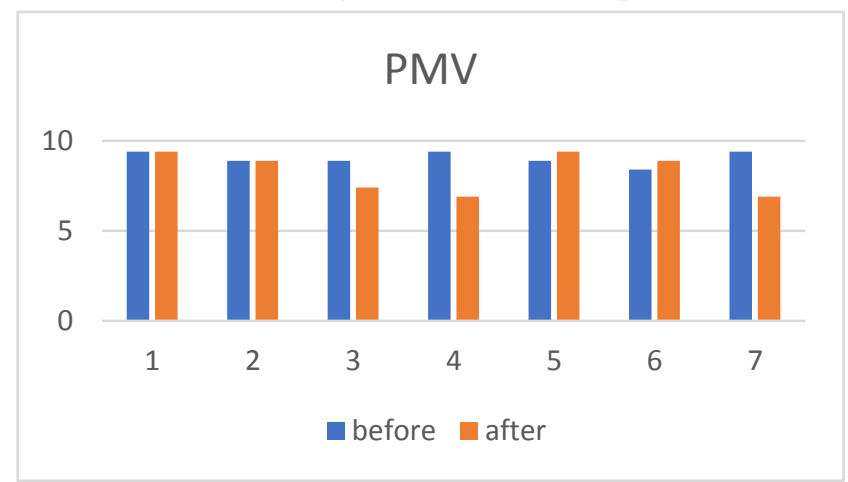

\section{C.2-SHUBRA AL-KHAIMAH}

Shubra Al-Khaimah district is one of the most crowded areas, so the road network is developing and doubling and the density of transportation increases rapidly, so I witnessed a change in many areas, where many bridges were established to solve the traffic crisis and avoid traffic tics, which led to an increase in the pollution problem and this increased the impact on human health and increased the rate Virus spread.

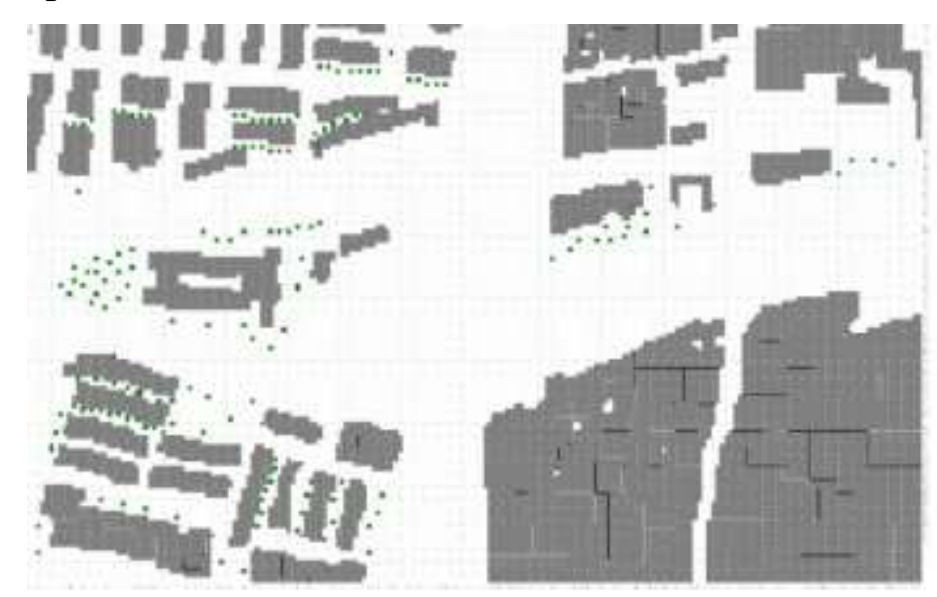

Figure 7 show the urban planning of the location in the simulation program.

Source: Envi mat programme 
Table 10 Ratios of the urban elements in the simulation.

\begin{tabular}{|l|l|l|}
\hline & before & after \\
\hline public space & 0 & 7.4 \\
\hline green area & 0.5 & 4.06 \\
\hline car road & 62.32 & 27.2 \\
\hline pedestrians & 0 & 17.4 \\
\hline cycle lane & 0 & 6.76 \\
\hline building & 37.18 & 37.18 \\
\hline
\end{tabular}

- The car road ratio includes $1.4 \%$ for parking area

Buildings in new design have green roof for storm water management

Table 9 Evaluation of space. source: By the researcher

\begin{tabular}{|c|c|c|}
\hline & Elements & Evaluation \\
\hline & Provide legible, connected street network & \\
\hline & provide safe pedestrian & \\
\hline ฮั & Provide traffic planning & \\
\hline 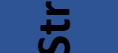 & interesting and safe streets & \\
\hline & $\begin{array}{l}\text { encourages walking, through small } \\
\text { connected blocks }\end{array}$ & \\
\hline & Locate public transport stops & \\
\hline & supports public transport & \\
\hline 논 & $\begin{array}{l}\text { distances that need to be travelled between } \\
\text { activities. }\end{array}$ & \\
\hline 용 & Mixed use development & \\
\hline$\frac{\sqrt{5}}{\sqrt{2}}$ & $\begin{array}{l}\text { makes driving, walking and cycling more } \\
\text { pleasant }\end{array}$ & \\
\hline & enables the adverse effects of transport & \\
\hline & reduces the need to travel. & \\
\hline & supports walking and cycling. & \\
\hline & Walkable nodes people. & \\
\hline & Promote higher density residential activities. & \\
\hline 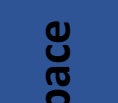 & $\begin{array}{l}\text { Link landmarks and nodes with strongly } \\
\text { defined paths. }\end{array}$ & \\
\hline$\frac{\pi}{n}$ & Use contrast and differentiation. & \\
\hline 응 & supports public spaces, creating safe. & \\
\hline 2 & $\begin{array}{l}\text { creates safety places that have little } \\
\text { movement. }\end{array}$ & \\
\hline & Protect ecologically & \\
\hline & Use large park areas & \\
\hline ᄃ & Provide for continuity of green & \\
\hline త్ర & Extend tree planting & \\
\hline U $\frac{2}{\frac{\pi}{6}}$ & Provide a diverse range of plant species & \\
\hline & Allow for stormwater treatment. & \\
\hline
\end{tabular}




\begin{tabular}{|c|c|c|}
\hline \multirow{3}{*}{ 胞 } & Promote mixed-use buildings. & \\
\hline & improves energy efficiency & \\
\hline & helps form active 'edges' & \\
\hline & minimum & high \\
\hline
\end{tabular}

\section{SIMULATION RESUlTS IN Shubra Al-Khaimah}

1- Figure 8 Air temperature reduction is $3: 4{ }^{\circ} \mathrm{C}$ after redesign. source: By the researcher

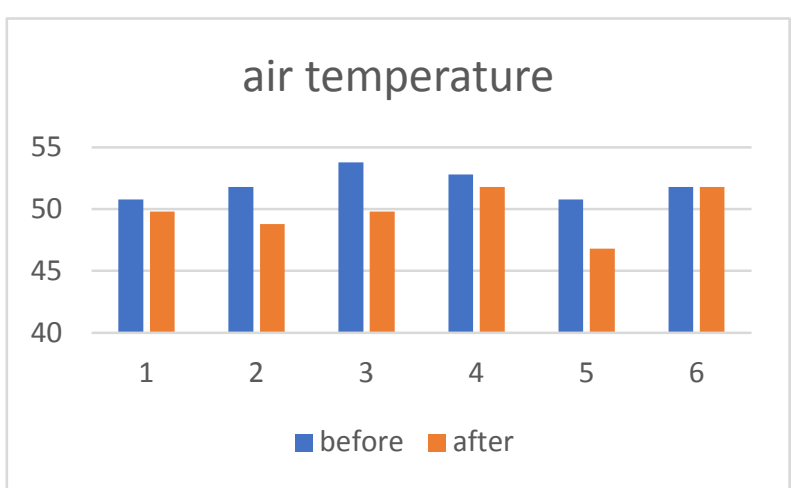

2- Figure 9 Relative humidity ratio increased about $2 \%$ - 3\%. source: By the researcher

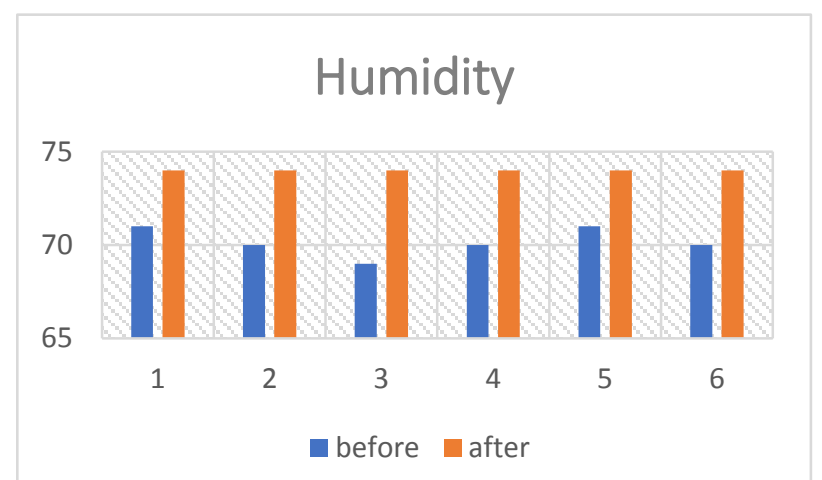

3- Figure 10 Wind speed reduction average is $0.5 \mathrm{~m} / \mathrm{s}-1.5 \mathrm{~m} / \mathrm{s}$. source: By the researcher

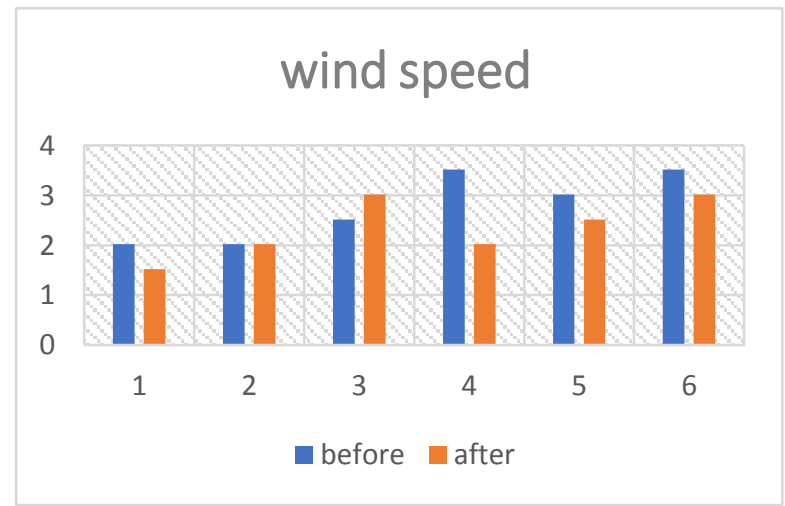


4- Figure $11 \mathrm{Co}_{2}$ reduction average is $0.06 \mathrm{mg} / \mathrm{m}^{3}$ in the space. source: By the researcher

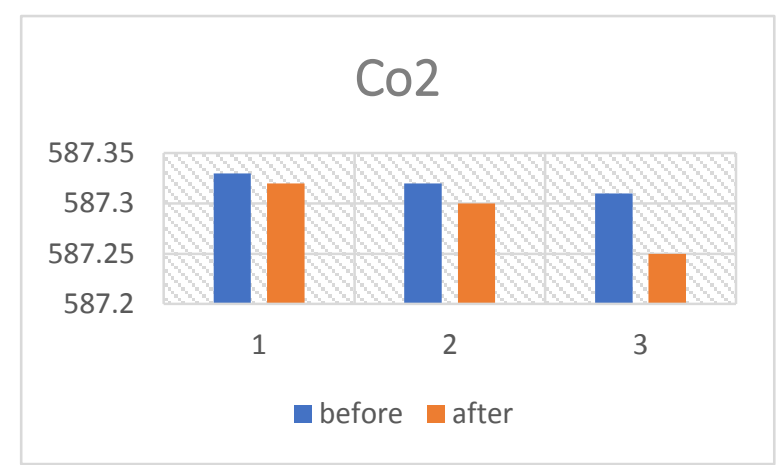

5- Figure 12: PMV reduction average is 2 in urban space. source: By the researcher

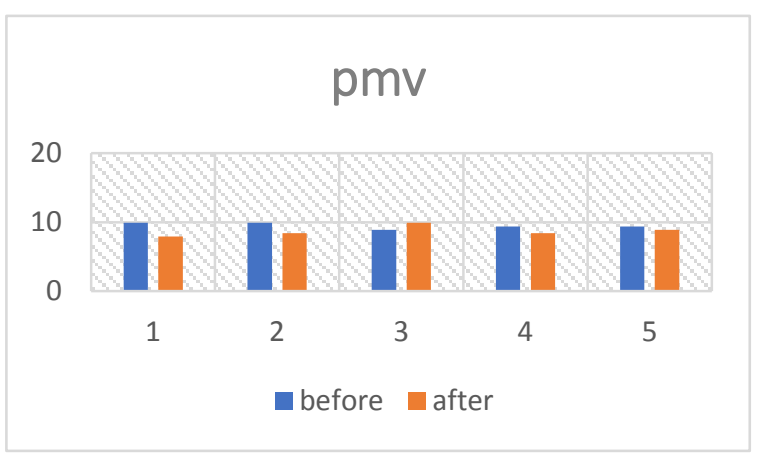

\section{C.3-ROXY, MISR EL-GADEDA}

Modern Heliopolis was originally filled primarily with aristocratic Egyptians, as well as some European nationals. Unlike other modern Cairene suburbs around the start of the 20th century, Heliopolis had a significantly larger percentage of Egyptian citizen residents. After the 1952 revolution led by Nasser, it became home to too much of Cairo's educated middle class. As Cairo has expanded, the once large distance between Heliopolis and Cairo has vanished and it is now well inside the city.

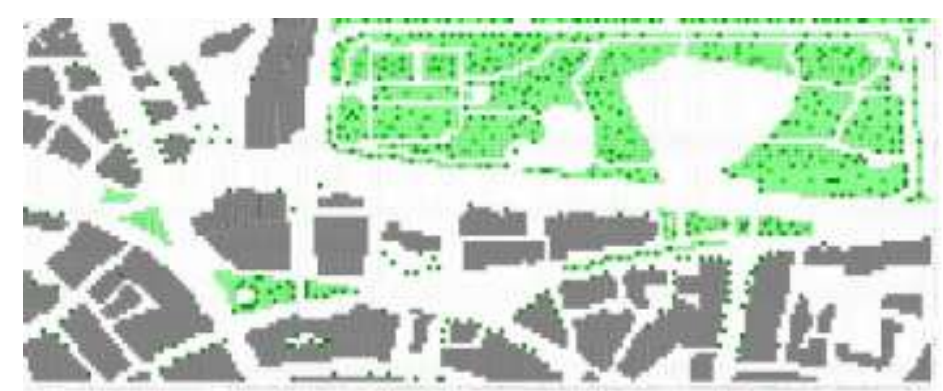

Figure 13 show the urban planning of the location in the simulation program.

Source: Envi mat programme

- Table 11 Evaluation of space

\begin{tabular}{|c|c|c|}
\hline & Elements & Evaluation \\
\hline \multirow{4}{*}{ ஸे } & Provide legible, connected street network & \\
\hline & provide safe pedestrian & \\
\hline & Provide traffic planning & \\
\hline & interesting and safe streets & \\
\hline
\end{tabular}




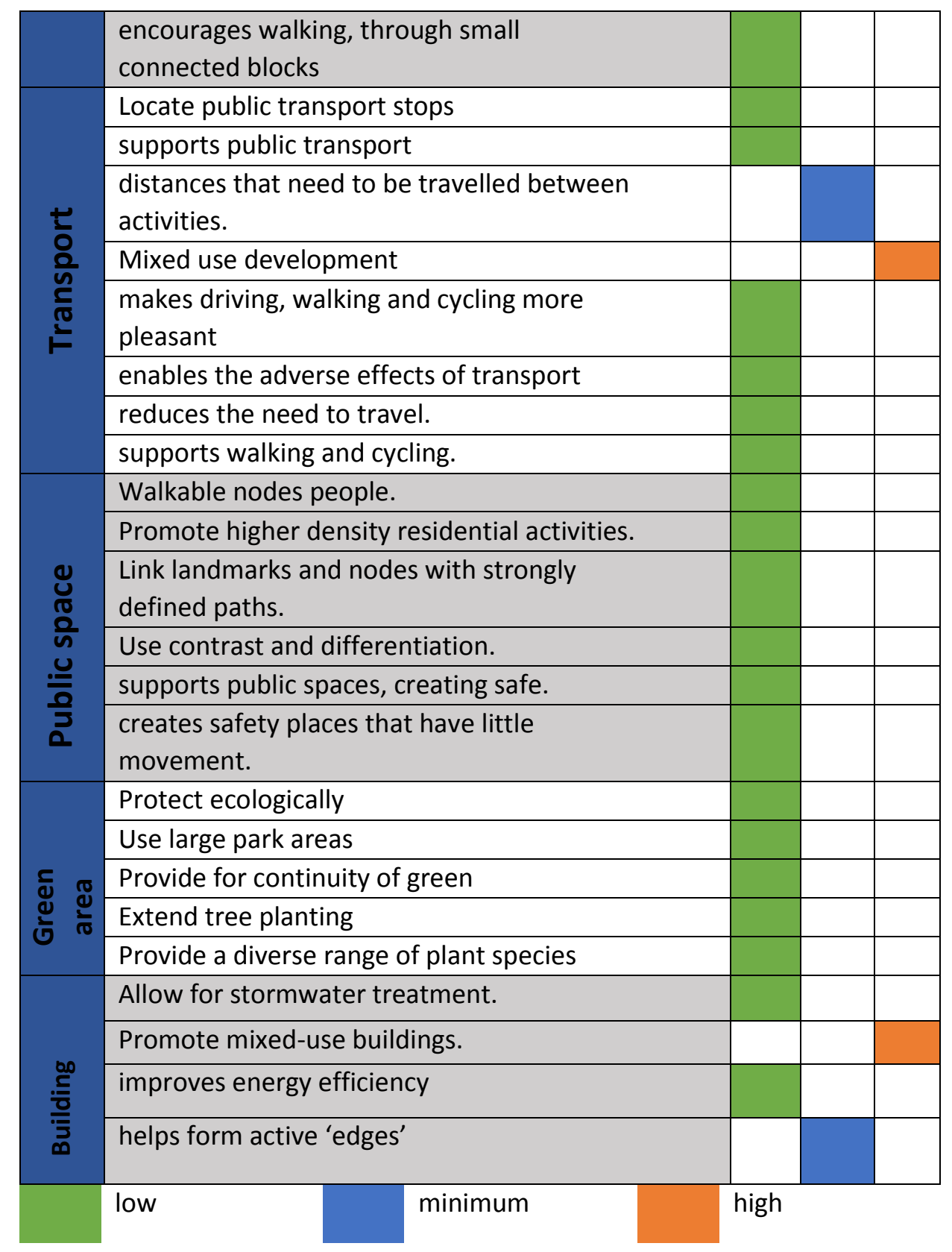

-Table 12 Ratios of the urban elements in the simulation program.

\begin{tabular}{|l|l|l|}
\hline & before & after \\
\hline public space & $\mathbf{6 . 3}$ & 7.1 \\
\hline green area & $\mathbf{1 3 . 6}$ & 14.4 \\
\hline car road & $\mathbf{1 5 . 5}$ & 12 \\
\hline pedestrians & $\mathbf{3 5 . 3}$ & 31.2 \\
\hline cycle lane & $\mathbf{0}$ & 6 \\
\hline building & $\mathbf{2 9 . 3}$ & 29.3 \\
\hline
\end{tabular}

- The car road ratio includes $0.9 \%$ for parking

- Buildings in new design have green roof for storm water management. 


\section{Simulation RESUltS IN Roxy, Misr El-Gadeda}

1- Figure 14 Air temperature reduction is $1: 2{ }^{\circ} \mathrm{C}$ after redesign. source: By the researcher

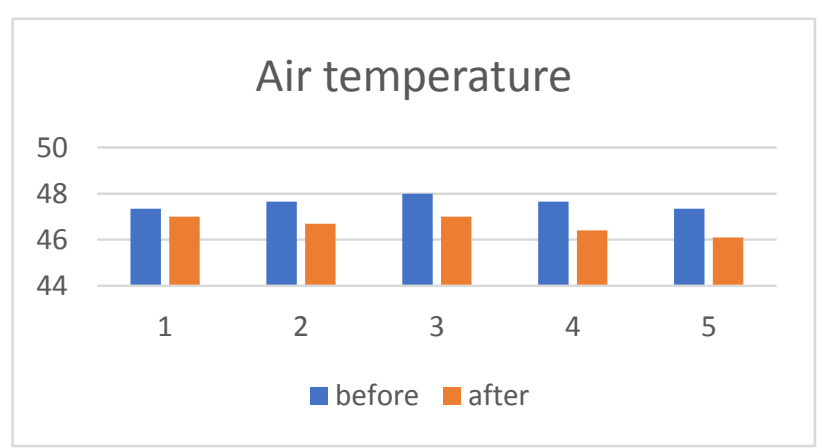

2- Figure 15 Relative humidity ratio reduction about $1.5 \%$. source: By the researcher

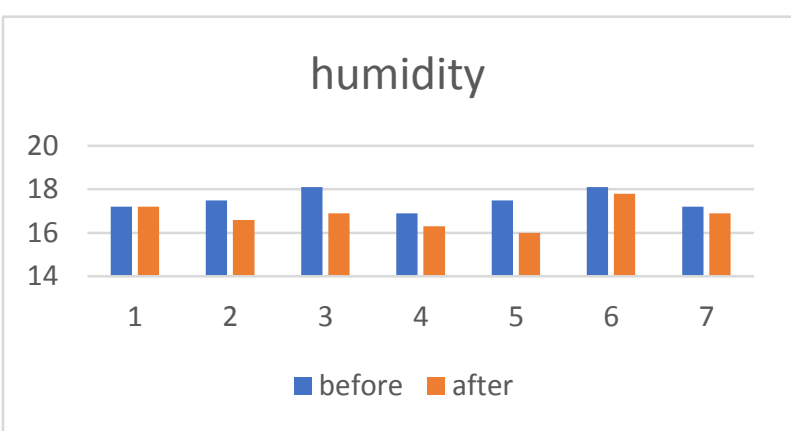

3- Figure 16 Wind speed reduction average is $0.5 \mathrm{~m} / \mathrm{s}-1.8 \mathrm{~m} / \mathrm{s}$. source: By the researcher

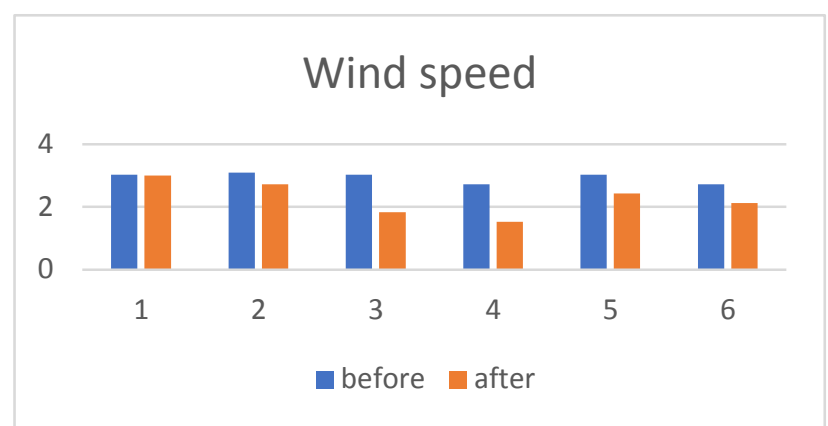

4- Figure $17 ; \mathrm{Co}_{2}$ reduction average is $0.3 \mathrm{mg} / \mathrm{m}^{3}$ in the space. source: By the researcher

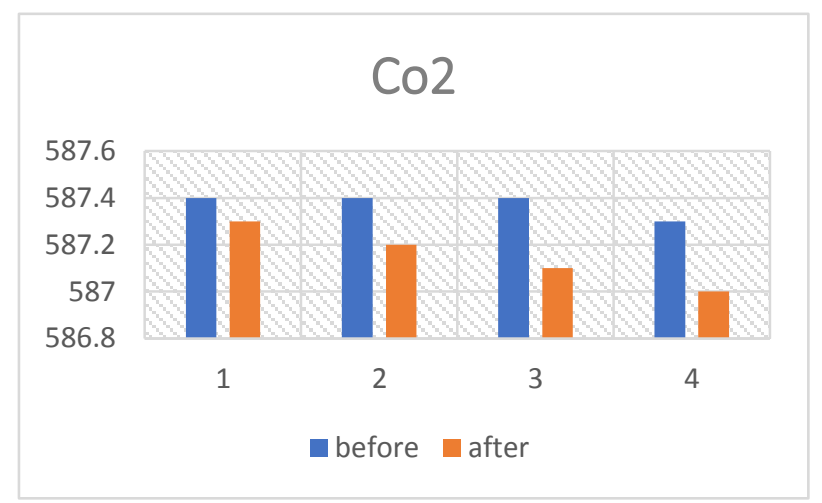


5- Figure 18; PMV reduction average is 2 in urban space. source: By the researcher

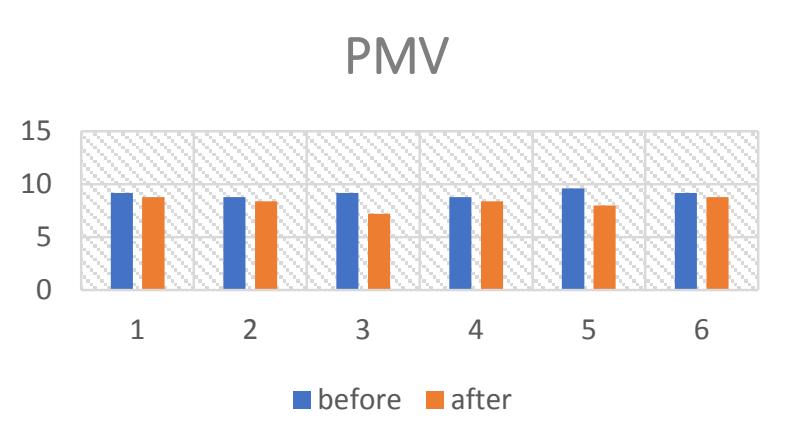

\section{D- COMPARISON BETWEEN CASE STUDIES}

\begin{tabular}{|c|c|c|c|c|}
\hline & Obour city & Roxy & Shubra Al-Khaimah & result \\
\hline $\begin{array}{c}\text { Air } \\
\text { temperature }\end{array}$ & $\begin{array}{l}\text { Air temperature } \\
\text { reduction is } 2: 3{ }^{\circ} \mathrm{C} \\
\text { after redesign }\end{array}$ & $\begin{array}{l}\text { Air temperature } \\
\text { reduction is } 1: 2{ }^{\circ} \mathrm{C} \\
\text { after redesign. }\end{array}$ & $\begin{array}{l}\text { Air temperature } \\
\text { reduction is } 3: 4{ }^{\circ} \mathrm{C} \\
\text { after redesign }\end{array}$ & $\begin{array}{l}\text { Air temperature } \\
\text { reduction about } 1: 4^{\circ} \mathrm{C}\end{array}$ \\
\hline Humidity & $\begin{array}{l}\text { Relative humidity } \\
\text { ratio reduction is } \\
1 \%-1.4 \%\end{array}$ & $\begin{array}{l}\text { Relative humidity } \\
\text { ratio reduction about } \\
1.5 \%\end{array}$ & $\begin{array}{l}\text { Relative humidity } \\
\text { ratio increased about } \\
2 \%-3 \%\end{array}$ & $\begin{array}{l}\text { Humidity increase in } \\
\text { high density areas } \\
\text { about } 3 \% \text {, but in low } \\
\text { density area decreasd } \\
\text { about } 1.5 \% \text {. }\end{array}$ \\
\hline Wind speed & $\begin{array}{l}\text { Wind speed } \\
\text { reduction average } \\
\text { is } 0.5 \mathrm{~m} / \mathrm{s}-1 \mathrm{~m} / \mathrm{s}\end{array}$ & $\begin{array}{l}\text { Wind speed reduction } \\
\text { average is } 0.5 \mathrm{~m} / \mathrm{s}-1.8 \\
\mathrm{~m} / \mathrm{s}\end{array}$ & $\begin{array}{l}\text { Wind speed reduction } \\
\text { average is } 0.5 \mathrm{~m} / \mathrm{s}- \\
1.5 \mathrm{~m} / \mathrm{s}\end{array}$ & $\begin{array}{l}\text { Wind speed reduction } \\
\text { about } 0.5 \mathrm{~m} / \mathrm{s}-1.8 \mathrm{~m} / \mathrm{s}\end{array}$ \\
\hline $\mathrm{Co}_{2}$ & $\begin{array}{l}\mathrm{Co}_{2} \text { reduction } \\
\text { average is } \\
0.02 \mathrm{mg} / \mathrm{m}^{3} \text { in the } \\
\text { space }\end{array}$ & $\begin{array}{l}\mathrm{Co}_{2} \text { reduction average } \\
\text { is } 0.3 \mathrm{mg} / \mathrm{m}^{3} \text { in the } \\
\text { space }\end{array}$ & $\begin{array}{l}\mathrm{Co}_{2} \text { reduction average } \\
\text { is } 0.06 \mathrm{mg} / \mathrm{m}^{3} \text { in the } \\
\text { space. }\end{array}$ & $\begin{array}{l}\mathrm{Co}_{2} \text { level reduced } \\
\text { average about } 0.02 \text { : } \\
0.3 \mathrm{mg} / \mathrm{m}^{3} \text {. } \\
\text { The reduction } \\
\text { changing according to } \\
\text { many variables }\end{array}$ \\
\hline PMV & $\begin{array}{l}\text { PMV reduction } \\
\text { average is } 2 \% \text { in } \\
\text { urban space }\end{array}$ & $\begin{array}{l}\text { PMV reduction } \\
\text { average is } 2 \% \text { in urban } \\
\text { space }\end{array}$ & $\begin{array}{l}\text { PMV reduction } \\
\text { average is } 2 \% \text { in } \\
\text { urban space }\end{array}$ & $\begin{array}{l}\text { PMV reduction } \\
\text { average is } 2 \%\end{array}$ \\
\hline
\end{tabular}

\section{E- CONCLUSION}

The growth of cities is a new trend that has major impacts on both the global and local environment and human health, so we start to solve urban spaces problems which effect on human health.

From previous study redesign urban spaces in Egypt can improve human health by:

$\checkmark$ reducing the ratio of car lanes

$\checkmark$ Create safe pedestrian lanes.

$\checkmark$ Create safe cycle lanes.

$\checkmark$ Increase green areas

$\checkmark$ Increase public spaces

This variable leads to:

$\checkmark$ Air temperature reduction 


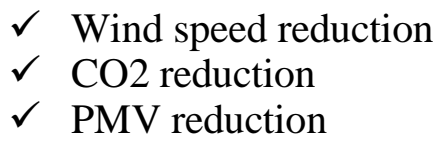

\section{F- RECOMMENDATION}

Now, we must take care of our spaces, buildings, and streets, everything around us affects our health and our lives, all the world is now suffering from the problem of the spread of COVID-19, we can reduce viruses spreading with our designs, we can stop its spread by using the suitable decision in our new urbanism.

\section{G- REFERENCES:}

1. Public health advisory committee, Minister of health, February 2008

2. Yosef Rafeq Jabareen, "Sustainable Urban Forms"Their Typologies, Models, and Concepts, Journal of Planning Education and Research, 2006

3. Nicola Dempsey, Caroline Brown, Shibu Raman, Sergio Porta, Mike Jenks, Colin Jones and Glen Bramley, "Elements of Urban Form" Oxford Institute for Sustainable Development, Oxford Brookes University, Oxford, UK,2010

4. Woodward A, Hales S, de Wet N." Climate Change: Potential effects on human health in New Zealand" Wellington Ministry for the Environment, 2001

5. Public Health Advisory Committee "healthy places, healthy lives: urban environments and wellbeing" A report to the Minister of Health, Wellington, New Zealand, April 2010, http://www.phac.health.govt.nz

6. https://en.climate-data.org/africa/egypt/qalyubia-governorate/al-obour-3828/ 